\title{
Does religious social capital affect farmland transactions? A spatial autoregressive analysis in Taiwan
}

\author{
Tsaiyu Chang ${ }^{1}$ (])
}

Received: 25 March 2021 / Accepted: 15 August 2021 / Published online: 8 September 2021

(c) The Author(s) 2021, corrected publication 2021

\begin{abstract}
This study aims to empirically determine whether social capital affects farmland transactions in Taiwan. It uses a geographic information system to link the villagelevel data of the largest national farmland survey with the village-level data of religious groups, which are the most widely distributed civil society organizations. The combined data are analyzed using a spatial self-retrogression model. After controlling for farmland spatial adjacency, an increase in social capital brought an increase in the percentage of active leased farmland and a drop in the percentage of fallow farmland. Analysis of the 2015 cross-sectional data revealed that social capital was strongly conducive to the efficient allocation of farmland resources. While belong to irrigation associations can help to allocate farmland resources (as expected), this allocation is more greatly facilitated by the combination of religion and other traditions. Social capital in Taiwan helped to reduce the density of abandoned farmland, especially Daoist temples in religious communities. This study also used panel data to examine changes in within-village farmland tenancy rates. This analysis found that the identified effects of social capital may decline over time.
\end{abstract}

Keywords Spatial models $\cdot$ Land use $\cdot$ Panel data $\cdot$ Religion $\cdot$ Social capital

JEL Classification C21 $\cdot$ C23 $\cdot \mathrm{Q} 15 \cdot \mathrm{Z} 12 \cdot \mathrm{Z} 13$

\section{Research purpose}

Taiwan is limited in size and crowded in population; therefore, agricultural farmland is traded at prices far above the discounted present value with the expectation of diversion for non-agricultural purposes. Chang (2012) found that farmland price determinants are estimated by the hedonic approach, whereby not only the quality

Tsaiyu Chang

chang.tsaiyu@surugadai.ac.jp

1 The Faculty of Economics and Management, Surugadai University, Saitama, Japan 
but also factors related to conversion (population density and zoning regulations) influence price.

Due to the inescapably high price of agricultural land in Taiwan, most farmers prefer leasing to expand or commence novel agricultural operations. Chang and Takahashi (2018) empirically revealed three main drivers of reduced supply in the farmland-leasing market: the increase in farmland's theoretical price owing to expectations of diversion in areas with low farmland improvement and lenient diversion regulations; quality improvement; and participation barriers in the market. If non-market factors drive up farmland rents, it is relatively difficult to rent land, thus inhibiting new agricultural endeavors and impeding the development of new agricultural innovations.

Social capital has been identified as a vital factor in agricultural land transactions. In the United States, Katchova and Ahearn (2014) found that young farmers tend to lease farmland as a way to enter agriculture, while also emphasizing that, to lease reasonably priced land, young farmers must build social capital in the local community. Robison et al. (2002a, b) defined social capital as “a person's or group's sympathy toward another person or group that may produce a potential benefit, advantage, and preferential treatment for another person or group of persons beyond that expected in an exchange relationship" (p.6). This definition shows that social capital may change the terms of trade between people, including farmland trade. Researching farmland leases in various countries, including Taiwan, reveals that many farmers rent a proportion of their land, often at prices not necessarily based on formal market rents. Informal negotiation to obtain agricultural leases relies heavily on the relationship between farmland owners and landowners. Such leases may also be extended to future generations. Under a long-term lease, the landlord can monitor whether the tenant will take proper precautions to protect the soil. The relationship between the two sides is expected to be stable under a long-term lease. In some empirical analyses of the non-market factors influencing land rent, social capital is emphasized. Robison et al. (2002a, b) found that social capital influences the terms of farmland trade. They showed that farmland owners sell at lower prices to friends and good neighbors but require higher prices from strangers. Social capital relationships have also proven critical to agricultural industrialization by influencing contracts between suppliers, processors, and labor. Siles et al. (2000) surveyed 1500 farmland owners in Illinois, Michigan, and Nebraska in the United States to determine the impact of interpersonal relationships on transactions. The results revealed that personal relationships change the conditions and patterns of agricultural land transactions. Prior results thus suggest that research on agricultural land markets should consider social capital's importance.

However, among East Asian countries that have developed based on agriculture, Japan has the most relevant empirical studies on the link between farmland tenancy and social capital (e.g., (Takahashi et al. 2018)). Few empirical studies have been conducted in Taiwan. Some studies in rural sociology, such as Hoshi (2020), have shown that, unlike Japan, Taiwan has weak village cohesion. This may imply that the social capital of Taiwanese villages is rather weak. However, empirical studies are lacking in part due national statistical data limitations. This study is the first to use a geographic information system to link the village-level data of the largest 
national farmland survey in Taiwan with the village-level data of religious groups, which are the country's most influential civil society organizations (Shieh 2010), using a spatial self-retrogression model.

\section{Research methods}

In Robison et al.'s (1999) and Taylor and Featherstone's (2018) models, which simplify the impact of social capital on farmland transactions, the farmland owner's choice of tenant can be modeled as maximizing utility $U$ in the following terms:

$$
\max U=U(r, l(m(K))
$$

where $r$ is the market rental rate of the farmland, $l$ is the intrinsic productivity of the farmland, and $m$ is the cost of monitoring the tenant's behavior in protecting the soil and otherwise affecting the land's long-term productivity. The tenant may offer high rent for the land but then abuse it to maximize revenue. Thus, landowners will maximize utility by weighing higher rents against the cost of monitoring to protect land value. One possible alternative to monitoring is the social capital $K$ built between the tenant and landowner. However, if the landowner needs to find a new tenant, there will be search costs $\mathrm{n}: \partial m / \partial K<0$ where $m$ is the monitoring cost and $K$ is the social capital of the current tenant. These studies posit that landowners' choices can be made by analyzing two key points: the revenue $r$ and the monitoring cost $m$ of their land. They examined the hypothesis that greater social capital would lower rent and lead to more farmland transactions. In other words, the increase in the volume of farmland transactions is also a result of the increase in the size of farmland leases in the region. Thus, while in the empirical study by Taylor and Featherstone (2018), rent received was the dependent variable in the regression, while the explanatory variables were leasing relationship duration as well as landowner and farmland characteristics, this study use the farmland transaction variables as explained variable and use the variables representing social capital as explanatory variable because the data used are agricultural records for all villages in Taiwan.

\subsection{Literature on farmland transactions in Taiwan}

According to the 2019 statistics of the Council of Agriculture, Executive Yuan, Taiwan has an area of 3.169 million hectares, of which 790,000 hectares are arable land. The total area of rice farming in the two periods is 270,000 hectares, accounting for an average of $3.73 \%$ of Taiwan's total area and $17 \%$ of its arable land. Historical data from 2000 showed that the area under rice cultivation declined sharply. One of the policy objectives after joining the World Trade Organization is to adjust the agriculture structure and revitalize fallow farmland to balance production and marketing (Ferng 2009). Another objective of agricultural structural adjustment policies is to increase agricultural productivity.

Many researchers have pointed out that one of the reasons why the productivity of Taiwanese agriculture has been low for many years is the small scale of 
cultivation per farm unit (Chen 1987). According to Taiwan's 2000 Census of Agriculture, the area of land per farm household in Taiwan has been below 1 ha from the 1960 s to the present. In addition, the concentration of farmland to largescale farmers has not progressed, and $90 \%$ of the land managed by farmers with a farm size of 1 ha or less is their own. One of the reasons for this delay in structural adjustment is the behavior of small-scale farmers, who continue to operate their farms without giving up farmland ownership for asset holding purposes. One of the reasons behind this is said to be past farmland policy.

After World War II, Taiwan experienced food shortages because of the destruction of agricultural facilities and the influx of hundreds of thousands of mainland immigrants. To respond to these challenges, irrigation facilities were repaired and chemical fertilizers and farm machinery were introduced. Farmland reforms of the 1950s that followed the 3-7-5 rent reduction program of 1949 led to an increase in production incentives among those who became independent farmers. The 1953 3-7-5 rent and Land-to-the-Tiller Program, which deprived landowners of their farmland at cheap prices and gave it to tenant farmers, resulted in farmers being very careful when deciding whether and how to lease.

In 1973, the "Agricultural Development Ordinance" was enacted, and it was followed by policies to convert small farmers into independent farmers and to equalize land ownership. Based on Lin (1993), the agricultural land market is weakly efficient, but the rapid increases of farmland values in Taiwan cannot be properly explained by the residual returns to land. The historical total rate of returns to agricultural land are competitive with other investment alternatives, such as non-urban land, stocks, and interest rates, but the composition of the rate of returns is quite different. Lin (1993) found that the production rate of returns of farmland in Taiwan has reached a very low level in recent years, about 1-2 percent, and the total rate of returns mainly consists of the capital gains rate of returns, 6-8 percent. In addition to encourage diversion of fields and leaving land fallow, the Taiwan government enacted the "Agricultural Land Conversion Scheme" in 1995, which allowed for conversion of 160,000 ha of agricultural land to developed land. Chang (2012) showed that the total revenue from farmland conversion from 1992 to 2003 in Taiwan was 0.5-1.5 times that from crop production. Furthermore, farmland price analysis in the two years after May 2008 by a hedonic approach shows that not only the farmland quality, which raises agricultural profit, but also factors related to conversion as the population density and zoning regulations, influence farmland price.

The government has recently promoted policies known as "Small Landlords and Big Tenants" from 2009, and farmers have taken advantage of these policies; however, they still establish farmland leases through their own village relationships. Strong village-level interpersonal relationships can also effectively prevent the development of fallow land.

Therefore, we use each village's average area of cultivated land and the ratio of non-agricultural employment among farmers as factors that negatively affect the expansion of farmland leasing. In particular, if the willingness to work in non-agriculture is high, we assume that there is a willingness to convert farmland to nonagricultural uses. 
In addition to the capitalization of farmland, the lack of progress in the liquidation of farmland in Taiwan can be attributed to problems related to the fallow policy and the farmland leasing system. First, subsidies are paid for fallow land, which makes it impossible for tenants to rent farmland unless they pay a higher rent than the subsidy. In addition, the fact that there is a 3-7-5 rent reduction to protect small farmers, and that rice cultivation is subdivided into different work types, and all except for administrative labor is outsourced, also hinders farmland leasing.

Therefore, in addition to the degree of farmland leasing in each village, the ratio of crop fallow and work outsourcing in each village are also important targets of analysis here.

\subsection{Religion}

Other studies have used religious affiliations as social capital variables with potential influence on farmland transactions. Raup (2003) noted that the transfer of farmland for agricultural purposes is mainly owing to death or retirement, and that people tend not to sell inherited farmland. There is a cultural element behind the farmland market, such as transfer based on religious beliefs and practices. Villages with a strong religious influence have a strong commitment to rural lifestyles and the ability to motivate resident families. Therefore, agricultural markets in religious-based societies are driven by factors other than the economy.

As Hoshi (2020) noted, the family is the most basic social unit of society in Taiwan. Ishida (1981, 1984a, 1984b) found that in agricultural communities far from the district and administrative centers, the blood ties between families remain high. However, in religious rituals, there is often a close social unit extending beyond the family. In traditional rituals, core family members must be represented and take turns performing rituals; however, adult males with families in other areas are exempt. For example, when praying to God of Heaven, it is necessary to read out the names of each family in a memorial to the gods, and through these religious activities, a bond is created within families.

Beliefs in Taiwan are liberal. Temples generally belong to folk religions, so they do not state that they adhere to Daoism and Buddhism, though participants often consider their beliefs to be Buddhist or Daoist. The authorities also classify them as such for convenience. Buddhism is more spiritual, and Daoism the more social. Taiwan's popular beliefs, which are often divided into Daoism and Buddhism, are often very regional, known as folk beliefs. The customs and habits of folk beliefs are closely related to those of agrarian society. Although urbanization has led to young people's departure, the older generation has become more attached to folk beliefs. They also share a common sense of community while performing rituals together. A feast, called "bai-bai," follows the ritual; sumptuous food accompanies the feast, symbolizing a good harvest. Farmers believe the land is under the Lord of the Earth's care, and is the source of all crops and plants. Therefore, if they want a good harvest, they have to rely on the Lord of the Earth's blessing. Another connection between agriculture and religion is the use of water for irrigation. Especially in areas dominated by rice cultivation, people 
used to fight for water; religious activities were used to unite people who shared a canal. There are also rituals to commemorate those who die when digging a canal. Many of these traditions persist.

Temple management in Taiwan is nowadays responsive to modernization because they will perform rituals for people without requiring the direct participation of the faithful. Shieh (2010) calls this the "separation of human and religious work." Daoist monks usually practice asceticism, and people have strong contact with the monks during rituals; but afterwards, they return to work, which means people only donate during ceremonies, but do not participate much in general. Although participation in Taiwanese temples has become less obligatory, believers often organize activities and take bus trips together, mainly to visit other areas with famous temples to worship and burn incense (i.e., "Jing-shian"). In this type of tour, believers spend time socializing on the bus, dine in restaurants near the temple, stay together in hotels, and pay for a package tour; it has become an important part of Taiwan's tourism industry. There are also links between temples located in proximity. In Taiwan, where the family is the basic unit, religion is an important mechanism for connecting families and is a key factor in defining bonds above the family level. Religion is also an indispensable element in the study of agricultural activities. However, it is not easy to quantify this factor in empirical studies. This study will also contribute to the literature on religious using quantitative methods.

\subsection{Irrigation association}

Taiwan is an island with high mountains in the center and very uneven rainfall distribution both temporally and spatially, resulting in fierce competition over irrigation water. Hence, the presence of irrigation associations is critical. As an important component of agricultural production, the irrigation association emerged in Taiwan in 1922. There are currently 17 farmer-organized irrigation associations. Each is a public corporation, and participation is semi-compulsory. These associations have employed several irrigation engineers to design water reservoirs to control the supply and improve water collection. In addition, hydrological engineers have been directly or indirectly involved in educating farmers to use and control these irrigation technologies.

This relationship between irrigation association and farmers undoubtedly forms a social network. This study considers the rate of membership calculated by area in irrigation associations as an important social capital variable. In recent years, irrigation associations have been facing increasing financial autonomy because of the fiscal deficit; from October 2020, they became fully managed by a government department: the Irrigation Agency, Council of Agriculture, Executive Yuan. The suspension of dues because of government subsidies could solve the financial deficit. Water utility staff would become civil servants and it would lose mutual aid society status. Members would not have to pay to maintain water facilities, but all would continue to benefit from irrigation. This may reduce the social network function of irrigation facilities. 


\subsection{Study subject: villages}

The main unit of study is the village ("Tsuen-ri"). Villages exist as subordinate units of towns. They are generally united by territory, lineage, religion, etc. In Taiwan, the village is an administrative unit formed in the era of Japanese rule through reform of the neighborhood administrative system. In other words, the present village prototype was not formed naturally. The natural and administrative villages do not always overlap. However, under Japanese rule, the village had its own community ties that developed for more than a hundred years, thereby evolving a community function.

To promote community formation, the Taiwanese government enacted laws on the formation of autonomous units. The 1983 Regulations on Community Development Work defined the community, stipulating that "the community areas shall be allocated according to such factors as historical relationship, cultural background, geographic status, population distribution, ecological characteristics, resources, modality of houses, and development of agriculture, fishing, industry, mining, and commerce as well as the intent, interest, and common needs of the residents." However, the board of directors for Regulations on Community Development Work was reorganized in 1991. While the board considered the history, cultural background, and resident wishes, the scope of the community was defined as organizations operating within the administrative district. In other words, the boundaries of an administrative village were roughly set to correspond with the activities of a social area, entailing not only spatial but also human overlap. Nevertheless, the literature had discussed Taiwanese settlements as centered on religious orders and temples, thus lacking a cohesive spatial or regional unit (Shieh 2010). A village contains about 100 households in a low-density area but as many as 1000-4000 households in a densely populated area. The importance of considering can be seen from previous empirical studies. The importance of considering the linkages between regions can be seen from the empirical studies of Brekke et al. (1993). Brekke et al. (1993) surveyed residents of Minnesota over 40 years, from 1953 to 1992, and found that about two-thirds of farmland purchases were made by buyers who lived less than 10 miles from the tract of land purchased. Further, purchases by buyers who did not live locally were concentrated in high-risk areas that were farther from the market or had poorer soils. Therefore, this study considered spatial self-correlation important in farmland trade.

\section{Methods of estimation}

This study uses a spatial weighting matrix W in Stata 16.1 with a generalized spatial two-stage least squares (GS2SLS) estimator to estimate a spatial autoregressive model of $y_{i}$ with a specified spatial lag. In Eq. (2), $y_{i}$ is the use of land in each village; $K_{i, j}$ are social capital factors; $x_{i, j}$ is local farmland and employment status and industry status in the village $i$; and $\delta_{i} W y_{i}$ is the spillover effect of farmland usage status to nearby villages. Because farmland is connected, if one wants to lease land, one will also seek to lease land in nearby villages. Because the errors are not always 
normally distributed, this study used the GS2SLS instead of maximum likelihood estimation to estimate a more robust standard error.

$$
y_{i}=\alpha+\beta_{i, j} K_{i, j}+\gamma_{i, j} x_{i, j}+\delta_{i} W y_{i}+\epsilon_{i}
$$

Here, $i$ is area, numbers 1 to $\mathrm{N} ; y_{i}$ is the dependent variable in area $i ; K_{i, j}$ is the $j$ th independent social capital variable in area $i ; x_{i, j}$ is the $j$ th independent variable in area $i$; and $\epsilon_{i}$ is the error (residual) in area $i$.

This study estimated two models, one distinguishing Daoist and Buddhist temples and the other using the total number of temples as an explanatory variable:

$$
\begin{aligned}
\text { Rentalarea }_{\mathrm{Rt}}= & \alpha+\beta_{\mathrm{i}, 1} \text { daoism }_{R t, i}+\beta_{\mathrm{i}, 2} \text { buddhism }_{R t, i}+\beta_{\mathrm{i}, 3} \text { waterassociation }_{R t, i} \\
& +\gamma_{\mathrm{i}, 1} \text { _rableland }_{R t, i}+\gamma_{\mathrm{i}, 2} \text { outemp }_{R t, i}+\gamma_{\mathrm{i}, 3} \text { rice }_{R t, i}+\gamma_{\mathrm{i}, 4} \text { cereal }_{R t, i} \\
& +\gamma_{\mathrm{i}, 5} \text { industrial }_{R t, i}+\gamma_{\mathrm{i}, 6} \text { vege }_{R t, i}+\gamma_{\mathrm{i}, 7} \text { fruit }_{R t, i}+\gamma_{\mathrm{i}, 8} \text { mushr }_{R t, i} \\
& +\gamma_{\mathrm{i}, 9} \text { flower }_{R t, i}+\gamma_{\mathrm{i}, 10} \text { othercrop }_{R t, i}+\gamma_{\mathrm{i}, 11} \text { cattle }_{R t, i}+\gamma_{\mathrm{i}, 12} \text { pig }_{R t, i} \\
& +\gamma_{\mathrm{i}, 13} \text {.hicken }_{R t, i}+\gamma_{\mathrm{i}, 14} \text { duck }_{R t, i}+\gamma_{\mathrm{i}, 15} \text { leisure }_{R t, i}+\gamma_{\mathrm{i}, 16} \text { cc }_{i}+\delta_{i} \text { Wy }_{i}+\epsilon_{i}
\end{aligned}
$$

$$
\begin{aligned}
\text { Rentalarea }_{\mathrm{Rt}}= & \alpha+\beta_{\mathrm{i}, 0} \text { temple }_{R t, i}+\beta_{\mathrm{i}, 3} \text { waterassociation }_{R t, i}+\gamma_{\mathrm{i}, 1} \text { arableland }_{R t, i} \\
& +\gamma_{\mathrm{i}, 2} \text { outemp }_{R t, i}+\gamma_{\mathrm{i}, 3} \text { rice }_{R t, i}+\gamma_{\mathrm{i}, 4} \text { cereal }_{R t, i}+\gamma_{\mathrm{i}, 5} \text { industrial }_{R t, i} \\
& +\gamma_{\mathrm{i}, 6} \text { vege }_{R t, i}+\gamma_{\mathrm{i}, 7} \text { fruit }_{R t, i}+\gamma_{\mathrm{i}, 8} \text { mushr }_{R t, i}+\gamma_{\mathrm{i}, 9} \text { flower }_{R t, i} \\
& +\gamma_{\mathrm{i}, 10} \text { othercrop }_{R t, i}+\gamma_{\mathrm{i}, 11} \text { cattle }_{R t, i}+\gamma_{\mathrm{i}, 12} \text { pig }_{R t, i}+\gamma_{\mathrm{i}, 13} \text { chicken }_{R t, i} \\
& +\gamma_{\mathrm{i}, 14} \text { duck }_{R t, i}+\gamma_{\mathrm{i}, 15} \text { leisure }_{R t, i}+\gamma_{\mathrm{i}, 16} \text { cc }_{i}+\delta_{i} \text { Wy }_{i}+\epsilon_{i}
\end{aligned}
$$

Table 1 shows the definitions of the variables.

This study connects the village-level data of the 2015 Census of Agricultural, Forestry, Fishery, and Animal Husbandry with the temple data of the National Religion Information Network collected in April 2014 by the Ministry of the Interior. There were 7851 villages in the original data. However, since the major farms are located on the main island of Taiwan, this study excluded the village data of the islands of Kinmen, Matsu, and Penghu. Furthermore, census records were excluded if there were missing data or if the number of participants was too small for the village to be identified. Finally, the data were merged into the Taiwan government map of 2019. The final sample size for spatial analysis was 7078 villages (Table 2).

As Table 2 shows, the highest percentage of land area rented within villages was in eastern Taiwan, followed by southern Taiwan; the lowest percentage was in north Taiwan. However, as Table 3 shows, southern Taiwan had the highest temple density, followed by eastern Taiwan; again, north Taiwan has the lowest density. Concerning temple categories, Daoism had the highest temple density in southern Taiwan, followed by mid Taiwan, while Buddhism had the highest temple density in eastern Taiwan, followed by southern Taiwan. Taiwan's folk beliefs are open, but believers often identify as either Buddhist or Daoist. Officially, therefore, they are also categorized as Buddhist or Daoist for convenience. Most land-related beliefs, such as the Earth God or the "Ma-Tsu" beliefs that bless the crossing of the sea, are classified as Daoist. Most Daoist temples have village activities (Hsu 1978; 
Table 1 Definitions of the variables

\begin{tabular}{|c|c|}
\hline Rentalarea_Rt & $\begin{array}{l}\text { The area of arable land of farmers and ranchers leased in the village/ the farm area } \\
\text { in the village. }\end{array}$ \\
\hline temple_Rt & The number of temples in the village/ the population in the village. \\
\hline daoism Rt & The number of Daoist temples in the village/ the population in the village. \\
\hline buddhism Rt & The number of Buddhist temples in the village/ the population in the village. \\
\hline Waterassociation_Rt & $\begin{array}{l}\text { The water supply area from irrigation association in the village/ the farm area in } \\
\text { the village. }\end{array}$ \\
\hline arableland $R t$ & $\begin{array}{l}\text { The average area of arable land in the village/ the number of the agricultural } \\
\text { households. }\end{array}$ \\
\hline outemp Rt & $\begin{array}{l}\text { The number of households with non-farm work in the village / the number of farm } \\
\text { households in the village. }\end{array}$ \\
\hline rice_Rt & $\begin{array}{l}\text { The number of farmers who mainly grow rice in the village / the number of farm } \\
\text { households in the village. }\end{array}$ \\
\hline cereal Rt & $\begin{array}{l}\text { The number of farmers who mainly grow miscellaneous cereals / the number of } \\
\text { farm households in the village. }\end{array}$ \\
\hline industrial_Rt & $\begin{array}{l}\text { The number of farmers who mainly grow industrial crops / the number of farm } \\
\text { households in the village. }\end{array}$ \\
\hline vegetable Rt & $\begin{array}{l}\text { The number of farmers who mainly grow vegetables / the number of farm house- } \\
\text { holds in the village. }\end{array}$ \\
\hline fruit $R t$ & $\begin{array}{l}\text { The number of farmers who mainly grow fruits / the number of farm households } \\
\text { in the village. }\end{array}$ \\
\hline mushr Rt & $\begin{array}{l}\text { The number of farmers who mainly grow mushrooms / the number of farm house- } \\
\text { holds in the village. }\end{array}$ \\
\hline flower Rt & $\begin{array}{l}\text { The number of farmers who mainly grow flowers / the number of farm households } \\
\text { in the village. }\end{array}$ \\
\hline othercrop Rt & $\begin{array}{l}\text { The number of farmers who mainly grow other crops / the number of farm house- } \\
\text { holds in the village. }\end{array}$ \\
\hline cattle Rt & $\begin{array}{l}\text { The number of farmers mainly engaged in cattle / the number of farm households } \\
\text { in the village. }\end{array}$ \\
\hline pig Rt & $\begin{array}{l}\text { The number of farmers mainly engaged in pig farming / the number of farm } \\
\text { households in the village. }\end{array}$ \\
\hline chicken $R t$ & $\begin{array}{l}\text { The number of farmers mainly engaged in chicken farming / the number of farm } \\
\text { households in the village. }\end{array}$ \\
\hline duck $R t$ & $\begin{array}{l}\text { The number of farmers mainly engaged in duck farming / the number of farm } \\
\text { households in the village. }\end{array}$ \\
\hline leisure Rt & $\begin{array}{l}\text { The number of farmers mainly operating leisure agriculture / the number of farm } \\
\text { households in the village. }\end{array}$ \\
\hline$C c$ & The city or the county that the village belongs to. \\
\hline
\end{tabular}

Okada 1937). Buddhism, by contrast, does not necessarily have a center of worship bounded by a certain area, owing to the Buddhist principle of universal access to all beings. Many temples, such as those that are privately owned or dedicated to nature worship, do not have a common village worship circle. However, the data only distinguishes between Daoist and Buddhist temples, and most are Daoist. However, this does not affect the use of temple density as a factor to represent the activity intensity of village communities in our explanatory variables. 
Table 2 Rental farmland density, categorized by zone

\begin{tabular}{|c|c|c|c|c|c|c|c|c|c|}
\hline \multirow[t]{2}{*}{ zone } & \multirow[t]{2}{*}{ Freq. } & \multicolumn{4}{|c|}{ Rentalarea_Rt } & \multicolumn{2}{|c|}{ Rt_customarea } & \multicolumn{2}{|c|}{ Rt_setasidearea } \\
\hline & & Mean & Std. Dev. & Min & Max & Mean & Std. Dev. & Mean & Std. Dev. \\
\hline 1. North Taiwan & 2492 & 0.0576 & 0.1152 & 0 & 0.98 & 0.0040 & 0.025 & 0.1086 & 0.177 \\
\hline 2. Mid Taiwan & 2132 & 0.1382 & 0.1565 & 0 & 1 & 0.0162 & 0.047 & 0.0298 & 0.079 \\
\hline 3. South Taiwan & 2139 & 0.1403 & 0.1802 & 0 & 1 & 0.0154 & 0.051 & 0.0574 & 0.106 \\
\hline 4. East Taiwan & 315 & 0.2907 & 0.2375 & 0 & 0.94 & 0.0135 & 0.056 & 0.0490 & 0.087 \\
\hline Total & 7078 & & & & & & & & \\
\hline
\end{tabular}

Table 3 Social capital density, categorized by zone

\begin{tabular}{|c|c|c|c|c|c|c|c|c|}
\hline \multirow[t]{2}{*}{ Zone } & \multicolumn{2}{|c|}{ temple_Rt } & \multicolumn{2}{|c|}{ daoism Rt } & \multicolumn{2}{|c|}{ buddhism Rt } & \multicolumn{2}{|c|}{$\begin{array}{l}\text { Water } \\
\text { Association } \\
\text { _Rt }\end{array}$} \\
\hline & Mean & Std. Dev. & Mean & Std. Dev. & Mean & Std. Dev. & Mean & Std. Dev. \\
\hline 1. North Taiwan & 0.0006 & 0.0014 & 0.00044 & 0.00113 & 0.00015 & 0.00061 & 0.32978 & 0.34692 \\
\hline 2. Mid Taiwan & 0.0009 & 0.0011 & 0.00069 & 0.00082 & 0.00019 & 0.00055 & 0.29322 & 0.33794 \\
\hline 3. South Taiwan & 0.0014 & 0.0019 & 0.00114 & 0.00161 & 0.00024 & 0.00066 & 0.24520 & 0.31396 \\
\hline 4. East Taiwan & 0.0008 & 0.0013 & 0.00054 & 0.00091 & 0.00026 & 0.00061 & 0.32942 & 0.32805 \\
\hline
\end{tabular}

Besides, as we review in 2.1, we predicted the average area of arable land per household in each village (arableland_Rt) and the non-farm work per household in each village ("outemp_R") would negatively affect farmland-leasing expansion. From Table 4, "arableland_Rt", the area of arable land allocated to each household, is the largest in the east, followed by the south, and the smallest in the north. This order is the same as that of "Rentalarea_Rt" in Table 2. The order of "outemp_R", the non-farm work per household in each village, is mid, southern, northern, and eastern, and the difference between zones is not large.

Concerning the ratio of the main products of households in each village, the proportion of rice was high in all regions, with mid Taiwan being the largest. The proportion of farmers with cereals as a primary crop is greater in the south; the proportion of farmers who grow industrial crops is greater in the east; these three items are likely to use larger land areas. Additionally, these variables affect farmland leasing in this paper. However, other major crops will also affect farmland leasing if demand expands.

The ratio of farmers who mainly grow vegetables is higher in the north; the ratio of farmers who grow fruits is higher in the south; and the ratio of farmers who grow mushrooms and flowers is higher in the mid part of the country. These three categories likely require less land for farming. In terms of livestock farming, the ratio of farmers raising cattle is higher in the east; the ratio of farmers raising pigs, chicken, and ducks is higher in the south. The amount of agricultural land needed for livestock farming depends on type, but Taiwan has little grazing, so the area needed is not large. Finally, the ratio of farmers who use their farmland mainly for leisure 
Table 4 Variables representing the characteristics of local agriculture, categorized by zone

\begin{tabular}{|c|c|c|c|c|c|c|c|c|}
\hline \multirow[t]{2}{*}{ zone } & \multicolumn{2}{|c|}{ arableland $R t$} & \multicolumn{2}{|c|}{ outemp Rt } & \multicolumn{2}{|l|}{ rice_Rt } & \multicolumn{2}{|l|}{ cereal Rt } \\
\hline & Mean & Std. Dev. & Mean & Std. Dev. & Mean & Std. Dev. & Mean & Std. Dev. \\
\hline 1. North Taiwan & 0.55920 & 0.40555 & 0.65732 & 0.19337 & 0.31774 & 0.26511 & 0.03905 & 0.06954 \\
\hline 2. Mid Taiwan & 0.65865 & 0.34085 & 0.69793 & 0.15307 & 0.38713 & 0.28843 & 0.07024 & 0.15070 \\
\hline 3. South Taiwan & 0.70413 & 0.43453 & 0.67337 & 0.16080 & 0.23162 & 0.23836 & 0.09196 & 0.14039 \\
\hline 4. East Taiwan & 1.37486 & 0.82206 & 0.64681 & 0.16516 & 0.23545 & 0.23668 & 0.08357 & 0.10751 \\
\hline \multirow[t]{2}{*}{ zone } & \multicolumn{2}{|c|}{ industrial_Rt } & \multicolumn{2}{|c|}{ vegetable Rt } & \multicolumn{2}{|l|}{ fruit $R t$} & \multicolumn{2}{|l|}{ mushr Rt } \\
\hline & Mean & Std. Dev. & Mean & Std. Dev. & Mean & Std. Dev. & Mean & Std. Dev. \\
\hline 1. North Taiwan & 0.03151 & 0.06148 & 0.30169 & 0.22533 & 0.11414 & 0.11996 & 0.00045 & 0.00551 \\
\hline 2. Mid Taiwan & 0.04062 & 0.09338 & 0.15885 & 0.14603 & 0.21102 & 0.23986 & 0.00285 & 0.01637 \\
\hline 3. South Taiwan & 0.04610 & 0.09114 & 0.15209 & 0.14570 & 0.35126 & 0.28720 & 0.00052 & 0.00463 \\
\hline 4. East Taiwan & 0.07384 & 0.10523 & 0.19293 & 0.17167 & 0.24593 & 0.19588 & 0.00030 & 0.00164 \\
\hline \multirow[t]{2}{*}{ zone } & \multicolumn{2}{|l|}{ flower Rt } & \multicolumn{2}{|c|}{ othercrop Rt } & \multicolumn{2}{|l|}{ cattle $R t$} & \multicolumn{2}{|l|}{ pig $R t$} \\
\hline & Mean & Std. Dev. & Mean & Std. Dev. & Mean & Std. Dev. & Mean & Std. Dev. \\
\hline 1. North Taiwan & 0.00440 & 0.01934 & 0.00971 & 0.02937 & 0.00035 & 0.00552 & 0.00359 & 0.01342 \\
\hline 2. Mid Taiwan & 0.00882 & 0.02836 & 0.03278 & 0.07283 & 0.00069 & 0.00495 & 0.00487 & 0.01149 \\
\hline 3. South Taiwan & 0.00610 & 0.01862 & 0.00712 & 0.01980 & 0.00123 & 0.01045 & 0.00730 & 0.01735 \\
\hline 4. East Taiwan & 0.00254 & 0.01310 & 0.01187 & 0.03653 & 0.00276 & 0.01274 & 0.00424 & 0.01162 \\
\hline \multirow[t]{2}{*}{ Zone } & \multicolumn{2}{|c|}{ chicken Rt } & \multicolumn{2}{|l|}{ duck Rt } & \multicolumn{2}{|l|}{ leisure Rt } & & \\
\hline & Mean & Std. Dev. & Mean & Std. Dev. & Mean & Std. Dev. & & \\
\hline 1. North Taiwan & 0.00350 & 0.01365 & 0.00047 & 0.00578 & 0.00280 & 0.01450 & & \\
\hline 2. Mid Taiwan & 0.00502 & 0.01331 & 0.00161 & 0.01382 & 0.00243 & 0.01126 & & \\
\hline 3. South Taiwan & 0.00549 & 0.01946 & 0.00177 & 0.01047 & 0.00101 & 0.00660 & & \\
\hline 4. East Taiwan & 0.00591 & 0.01709 & 0.00026 & 0.00327 & 0.00486 & 0.01143 & & \\
\hline
\end{tabular}

tourism is higher in the north. This may have a positive correlation with the metropolitan demand in the north.

Additionally, as reviewed in 2.1, to compare the impact on other farmland utilization and leasing, the target 2 is "Rt_customarea." The scale of operations increase through not only farmland purchase but also the provision of custom farming services. Custom farming is a particular type of contract farming in Taiwan: small farmers outsource all large-scale mechanical work to farmers or organizations that manage contractors and agricultural machinery. The machine work involved in custom farming includes raising seedlings, leveling the ground, transplanting rice, and harvesting crops. The person offering custom farming cultivates others' farmland and accrues labor and machinery operating costs. In Taiwan, full custom farming is very common (Chang and Takahashi 2018). Landowners who rent out their land cannot entrust the same land to others through custom farming; thus, there is a trade-off between 
rented land and contracted land. Therefore, we predict that social capital may have no impact or a negative impact on the utilization of custom farming.

In addition, Taiwan's farmland use includes areas that are voluntarily fallowed by farmers. Under Taiwan's Belong to Direct Payment Measure for rice farming, there is a set-aside premium that allows farmers to obtain a fallow subsidy by resting their land. Here we also look at the descriptive statistics for the fallow land percentage in the village ("Rt_setasidearea" in Table 2). Since fallowing results in a decrease of overall farmland, the expected signs of estimation will be predicted as opposite to the area of land leased.

\section{Findings}

\subsection{Analysis of 2015 data}

The spatial lag coefficient of the estimated proportion of leased land was significant at the $1 \%$ level. This means there was a positive correlation between the percentage of leased land in one village and the percentage of leased land in a neighboring village. Because of this spillover effect's significance, spatial autoregressive analysis is more suitable than multiple linear regression (LeSage and Pace 2009).

According to the cross-sectional results in Column (1) of Table 5, the social capital factors that have a significant positive impact on the percentage of arable land leased to farmers within a village were the density of temples per capita and the ratio of the total area of the village irrigation association. When distinguishing between Buddhist and Daoist temples, only the density of village Daoist temples had a significant positive impact on the percentage of land rented by village farmers; the density of Buddhist temples was non-significant. This may be influenced by the nature of the religion and the field of activity because Daoist rituals are usually more frequent and have a stronger regional dimension.

At the $1 \%$ significance level, the rented land percentage was higher if the average village farmer had a larger area under cultivation; a higher percentage of farmers employed in non-farm work had a negative impact on the percentage of rented land.

By industry, a higher proportion of farmers growing rice, cereals, industrial crops, vegetables, fruit trees, flowering plants, and other crops indicates a higher proportion of rented land in the village. Mushroom cultivation, however, had no significant effect. This could be because mushrooms are mainly grown in crop factories. Concerning livestock farming, the percentage of farmers with cattle, pigs, and chicken was also positively and significantly related to the leased land percentage, while the percentage of duck farmers was non-significant. The percentage of farmers operating in leisure farming was also non-significantly related to the percentage of leased land.

To compare the impact on other farmland utilization and leasing, the target variable was changed to the proportion of farmland under custom farming (Dai-Geng), referred to in Table 5 as "Rt_customarea." In Column (2) of Table 5, the spatial lag coefficient of the estimated proportion of custom farming was significant at the $1 \%$ level. When the dependent variable was the ratio of the area subjected to custom farming, no social capital factors had a significant positive impact. 


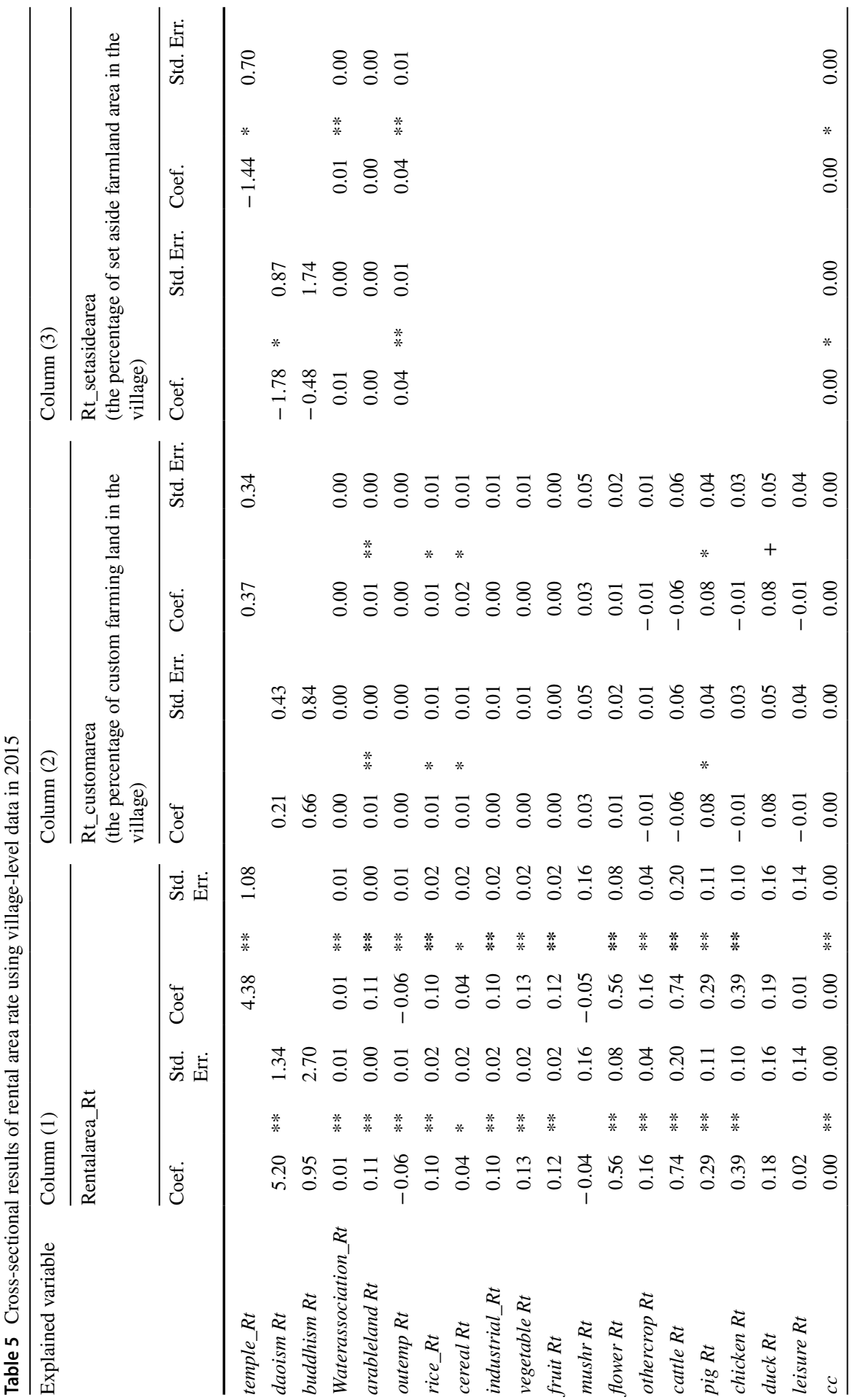




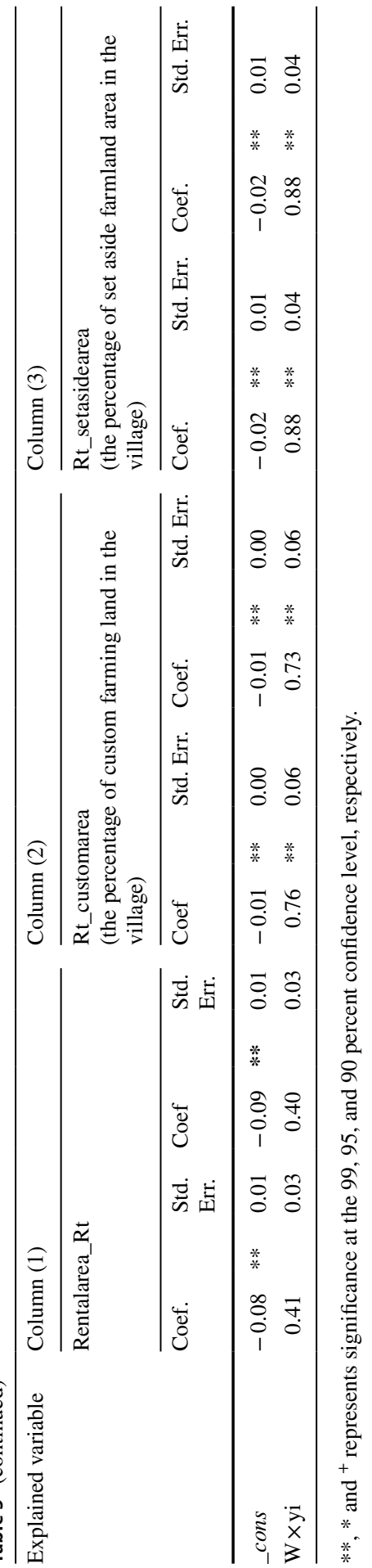


The higher the percentage of rice and cereal crops in a village, the higher the percentage of custom farming land. In contrast, there was no significant relationship between custom farming and the percentage of farmers growing special crops, vegetables, fruit trees, flowering plants, mushrooms, and other crops. This result reflects the situation in Taiwan, with rice farming being central and farmers consigning their land to third party operations. As for livestock production, villages with a higher percentage of pig and duck farmers had a higher percentage of custom farming land; however, there was no significant relationship with the percentages of cattle, chicken, and leisure farming operations.

In Column (3) of Table 5, the target variable is changed to the percentage of fallow farmland in the village ("Rt_setasidearea"). The spatial lag coefficient of the estimated proportion of fallow farmland was significant at the $1 \%$ level. Since fallowing is a policy related to rice farming, this analysis did not include industry-specific factors. The results showed that among the social capital factors, a higher density of temples per capita in a village negatively influenced the percentage of fallow land at the 5\% significance level. However, the effect of the participating ratio by area of the irrigation association was not significant. The density of Daoist temples in the village was significantly negatively related to the fallow farmland proportion, whereas the relationship with Buddhist temple density was not significant. These results are similar to those for the effects on leased land in Column (1). In addition, at the $1 \%$ significance level, a larger proportion of farmers with off-farm work indicated a higher proportion of fallow farmland; however, the average acreage of farmland did not have a significant impact.

\subsection{Analysis of the difference between 2005-2010 and 2010-2015}

This section used data for each of the villages from 2005, 2010, and 2015 to compare the change in farmland usage between 2005-2010 and 2010-2015. Data were processed using the variation in area (see Eq. (4) below), rather than the area ratio. After matching villages in the panel data of 2005, 2010, and 2015, the sample was reduced to 5710 villages. As data on social capital were only available for a single year (2015, or 2014 for the temples), these factors were fixed, assuming that neither the number of temples nor the rate of joining irrigation associations were likely to change significantly in 2005-2010 or 2010-2015 years. The subscript $D$ shows the difference between the two years in the numerator of Table 1.

$$
\begin{aligned}
\text { Rentalarea }_{D}= & \alpha+\beta_{\mathrm{i}, 1} \text { daoism }_{R t, i}+\beta_{\mathrm{i}, 2} \text { buddhism }_{R t, i}+\beta_{\mathrm{i}, 3} \text { waterassociation }_{R t, i} \\
& +\gamma_{\mathrm{i}, 1} \text { arableland }_{D, i}+\gamma_{\mathrm{i}, 2} \text { outemp }_{D, i}+\gamma_{\mathrm{i}, 3} \text { rice }_{D, i}+\gamma_{\mathrm{i}, 4} \text { cereal }_{D, i} \\
& +\gamma_{\mathrm{i}, 5} \text { industrial }_{D, i}+\gamma_{\mathrm{i}, 6} \text { vege }_{D, i}+\gamma_{\mathrm{i}, 7} \text { fruit }_{D, i} \\
& +\gamma_{\mathrm{i}, 8} \text { mushr }_{D, i}+\gamma_{\mathrm{i}, 9} \text { flower }_{D, i}+\gamma_{\mathrm{i}, 10} \text { othercrop }_{D, i} \\
& +\gamma_{\mathrm{i}, 11} \text { cattle }_{D, i}+\gamma_{\mathrm{i}, 12} \text { pig }_{D, i}+\gamma_{\mathrm{i}, 13} \text { chicken }_{D, i} \\
& +\gamma_{\mathrm{i}, 14} \text { duck }_{D, i}+\gamma_{\mathrm{i}, 15} \text { leisure }_{D, i}+\gamma_{\mathrm{i}, 16} \text { cc }_{i}+\delta_{i} \text { Wy }_{i}+\epsilon_{i}
\end{aligned}
$$

As Table 6 shows, when the change in the proportion of leased farmland area was the dependent variable, the spatial lag coefficient of the estimated change was 


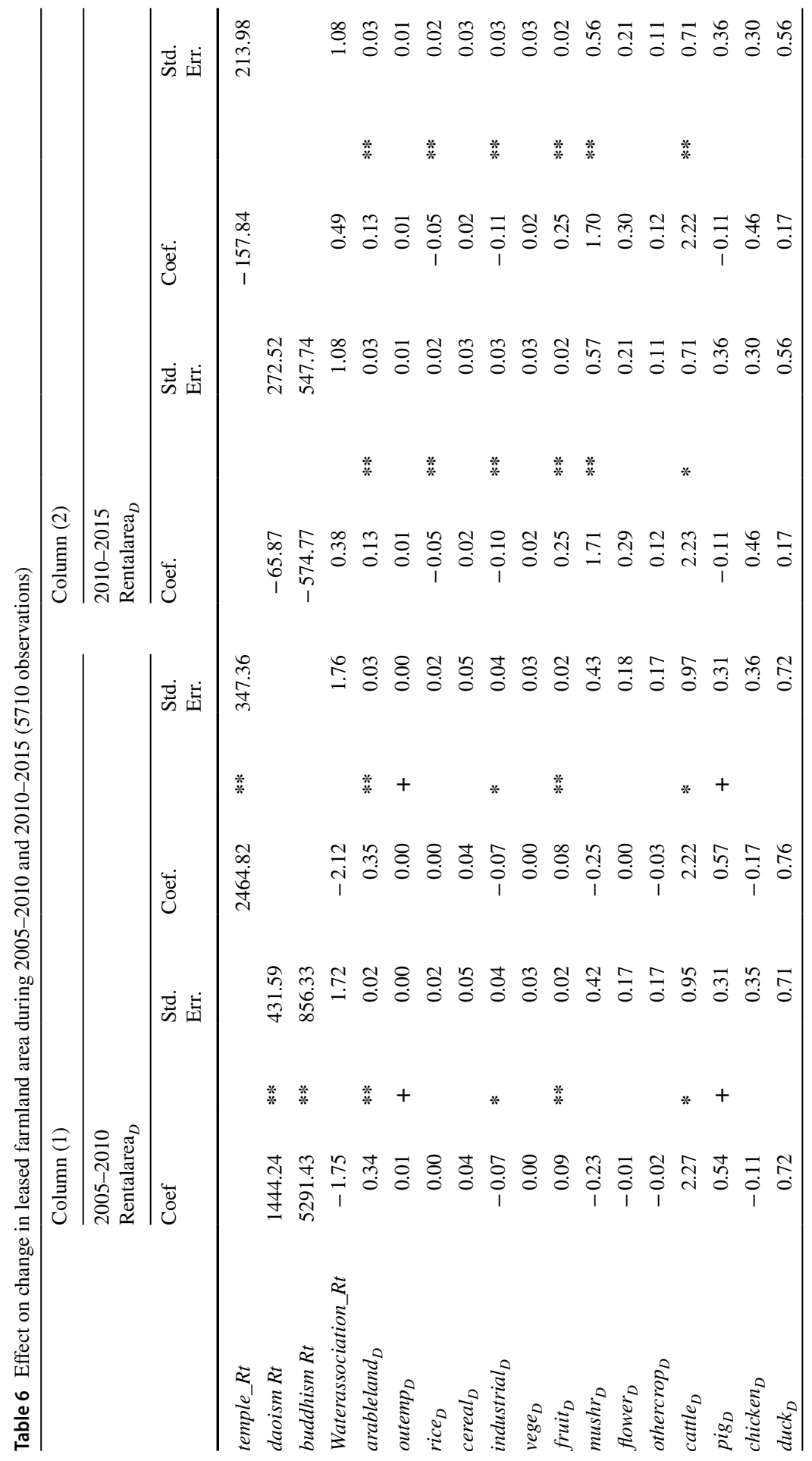




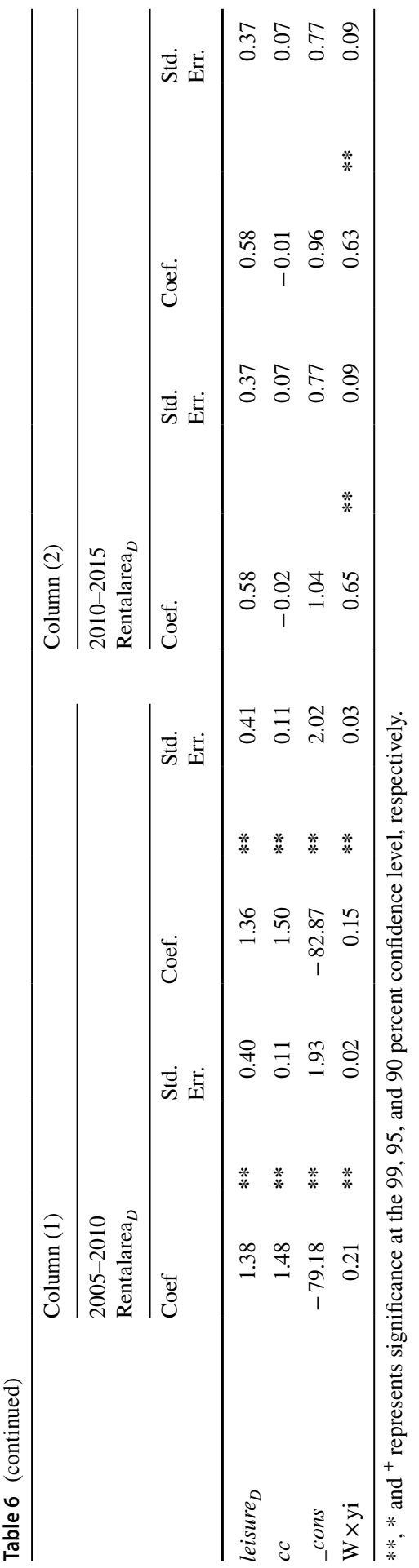


significant at the 1\% level during both 2005-2010 (Column (1)) and 2010-2015 (Column (2)). Regarding social capital, both the density of Daoist and Buddhist temples had a significant (1\% level) positive impact on the leased land area. However, the ratio of the area provided by the irrigation association was not significantly related to the proportion of leased land. At the $1 \%$ significance level, a larger increase in the average farmer's acreage $\left(\right.$ arableland $\left._{\mathrm{D}}\right)$ resulted in a larger increase in the area of leased land in the village. By contrast, the number of farmers employed, even outside the agricultural and pastoral industries, had a significant effect at the $10 \%$ level on the area of leased land in the village in 2005-2010.

In each industry, the increase in the number of farmers growing fruit trees predicted a high increase in the leased land area, at the $1 \%$ significance level. If the number of village farmers cultivating industrial crops decreased, the area of leased land in the village increased at the 5\% significance level. However, rice farming, cereals, vegetables, flowering plants, mushroom cultivation, and other crops were not significantly associated with the area of leased land. Increased proportion of cattle, pigs, and leisure farming operations significantly increased the area of leased land, but the proportions of chicken and duck operations had no significant effect.

The fruit tree, cattle, pigs, and leisure industries are among the higher valueadded industries in Taiwan; thus, the increase in the number of these farmers increased the demand for farmland, and these higher value-added farmers can afford to rent land, which also increased the amount of land that village farmers could rent from 2005 to 2010.

When the change in leased farmland area was the dependent variable in 2010-2015, the spatial lag coefficient of the estimated change in leased land area was significant at the $1 \%$ level, as shown in Column (2) of Table 6. No social capital factor had a significant positive impact, which may mean that the social influence of temples was lower than during 2005-2010. In addition, at the same 1\% significance level as 2005-2010, a greater increase in the average farmer's acreage from 2010-2015 indicated a greater increase in the area of leased land in the village. The number of village farmers employed in off-farm work no longer had a significant effect on the area of leased farmland in 2010-2015. By category of industry, the extent of fruit tree and mushroom cultivation were positively associated with the area of leased land at the $1 \%$ significance level from 2010 to 2015. Moreover, a fall in the number of village farmers cultivating rice and industrial crops was associated with a high increase in leased land area, at the $5 \%$ significance level. By contrast, farming of cereals, vegetables, flowering plants, and other crops had no significant impact. An increase in the proportion of cattle operations was associated with a significant increase in the leased land area, but the proportions of pigs, chicken, ducks, and leisure farming operations had no significant effect.

Different from 2005 to 2010, the proportions of cattle, fruit tree, and mushroom operations positively affected the leased land area in the village in 2010-2015; however, rice cultivation was negatively associated. Rice is the sector that uses most of Taiwan's farmland. To increase the number of small-scale farmland leases, Taiwan implemented a policy of small landowners and large tenant farmers for rice farming in 2010; however, it was largely ineffective. The leisure industry, which increased demand for farmland leases in 2005-2010, is saturated in Taiwan and did not significantly affect leased land during 2010-2015. 


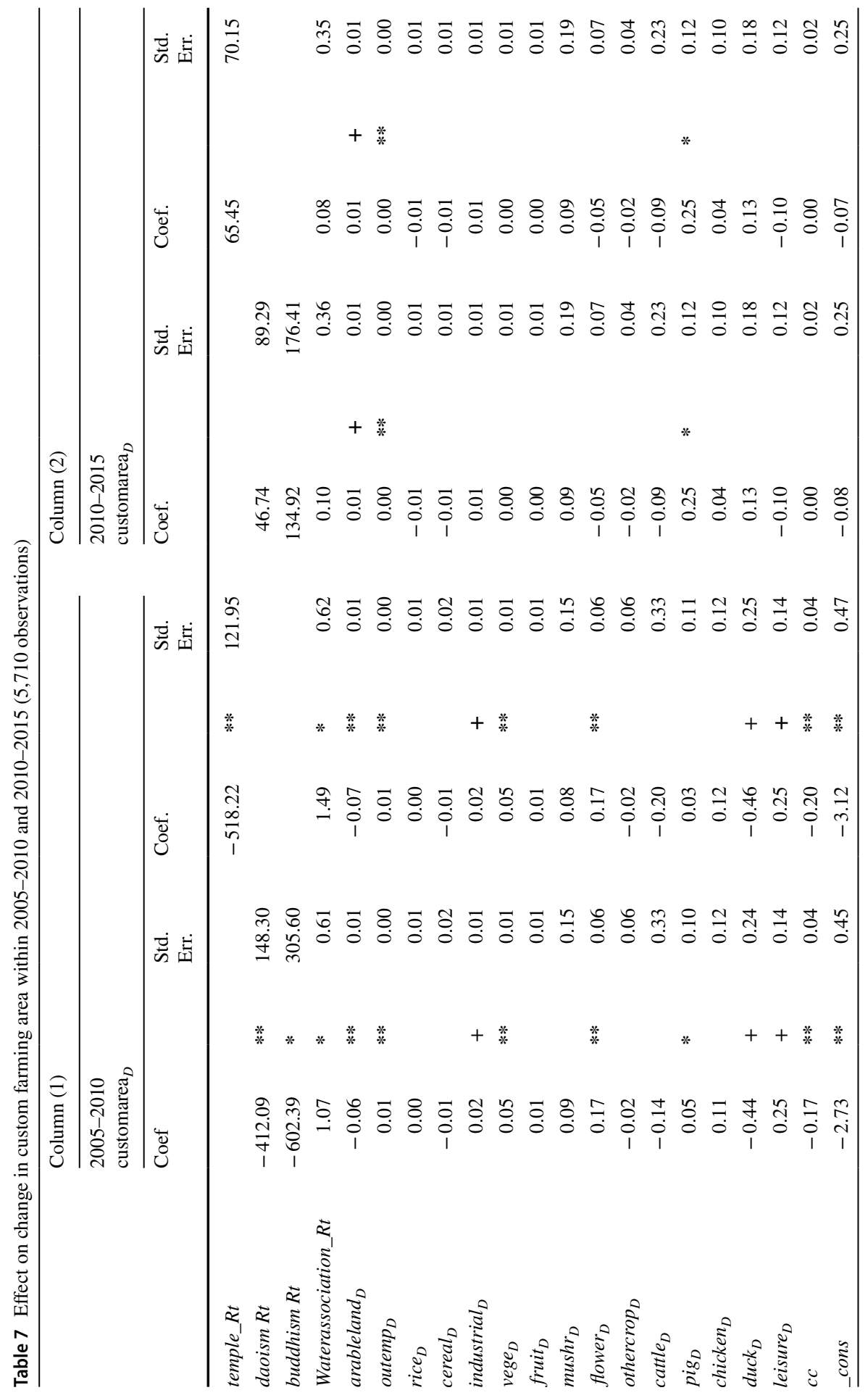




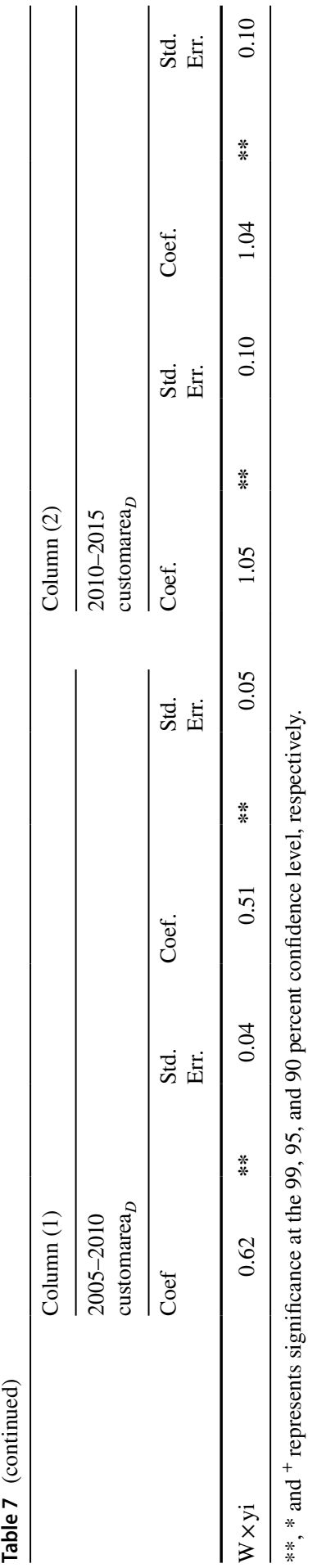


Next, the dependent variable was changed to the area of custom farming by the area of farming operations, referred to as "customarea ${ }_{D}$ " in Column (1) of Table 7.

In 2005-2010, the estimated spatial lag coefficient of the change in the custom farming area was significant at the $1 \%$ level. Temple density of temples per capita, including all temples, Daoist only, and Buddhist only, had a significant negative impact on the area of custom farming. As noted earlier, landowners who rent out their land cannot entrust their land to others through custom farming; thus, while religion had a positive effect on the leased land area in 2005-2010, its effect on the custom farming area was negative in 2005-2010. However, the change in the area contracted by the irrigation association had a significantly positive impact on the change in the custom farming area.

A larger increase in the average farmer's acreage between 2005 and 2010 was negatively related to the village's area of custom farming. The change in the number of village farmers employed in off-farm work had a significant positive impact on the village's custom farming area. The industries that significantly positively affected the area of custom farming within the village from 2005 to 2010 were industrial crops, vegetables, flowering plants, pigs, ducks, and leisure agriculture.

Finally, when the change in the area of custom farming during 2010-2015 was the dependent variable (Column (2) of Table 7), the spatial lag coefficient of the estimated change was significant at the $1 \%$ level. No social capital factor had a significant impact, nor did the density of temples, or the irrigated area of the water association, unlike in 2005-2010. The increase in the custom farming area was significantly larger if the increase in the average farmer's acreage in the village was greater, or if the number of farmers employed in off-farm work was greater. In addition, pig farming was the only industry to have a significant impact on the change in the custom farming area from 2010 to 2015.

\section{Discussion}

Here, the main finding is that social capital helps farmland transactions. After controlling for farmland spatial adjacency, an increase in social capital was associated with a rise in the percentage of leaded farmland leased in each village and a fall in the fallow farmland percentage. These results are consistent with the conclusion of previous studies on social capital's impact on farmland rents (Tan et al. 2018; Taylor and Featherstone 2016, 2018; Teshome et al. 2016), namely that social capital benefits the efficient allocation of farmland resources. In particular, analysis of the 2015 cross-sectional data revealed that social capital was strongly conducive to efficiently allocating farmland resources. Agricultural and irrigation associations, for example, are a direct form of social capital for agriculture. While the contribution of irrigation associations can help allocate farmland resources, as expected, the traditional combination of religion and other traditions was more effective in helping farmland resource allocation. Social capital represented by religions is often ignored in the literature. When examining the change in within-village farmland tenancy area from 2005 to 2010, the effect on tenancy area was significant, although it declined between 2010 and 2015. Conversely, social capital either had no impact on, or negatively affected custom farming 
contracts that did not require farmland leases. In addition, social capital helped to reduce the density of abandoned farmland, with the density of Daoist temples in religious communities especially influential. This finding suggests that village social capital plays an active role in the allocation of arable land resources.

Many reforms have been conducted in Taiwan's rural areas. In the post-war period, policies such as 3-7-5 rent reduction and Land-to-the-Tiller deprived landowners of farmland at cheap prices and gave it to tenant farmers. This later resulted in farmers being very cautious when deciding whether/how to lease out their farmland. Although, the government has recently promoted policies of farmland trade, where farmers can take advantage of subsidies, farmers still establish farmland leases through their own village relationships. Strong interpersonal relationships can also effectively prevent growth in fallow land. In addition, because the influence of social capital is declining, new farmers who had no chance to access older social capital still have the opportunity to lease farmland by investing in new social capital with landowners through policies such as "Small Landlords and Big Tenants" and good communication. This study also validates the idea that the government should continue supporting the establishment of farmland markets in rural areas, as well as helping farmers use social capital to find suitable farmland tenants.

Funding This work was supported by JSPS KAKENHI Grant Number 19K15921.

\section{Declarations}

Conflict of interest There is no conflict of interest to declare.

Open Access This article is licensed under a Creative Commons Attribution 4.0 International License, which permits use, sharing, adaptation, distribution and reproduction in any medium or format, as long as you give appropriate credit to the original author(s) and the source, provide a link to the Creative Commons licence, and indicate if changes were made. The images or other third party material in this article are included in the article's Creative Commons licence, unless indicated otherwise in a credit line to the material. If material is not included in the article's Creative Commons licence and your intended use is not permitted by statutory regulation or exceeds the permitted use, you will need to obtain permission directly from the copyright holder. To view a copy of this licence, visit http://creativecommons.org/licen ses/by/4.0/.

\section{References}

Brekke, J., Tao, H.L., Raup, P.M.: The Minnesota rural real estate market in 1992 (No. 1690-2016137319) Economic Report ER 93-5 and annual preceding reports, 1953 to 1992 (1993). https://doi. org/10.22004/ag.econ.13010

Chang, T.: A quantitative analysis of the farmland conversion problem in Taiwan. J. Rural Econ. 84(3), 172-184 (2012). https://doi.org/10.22004/ag.econ.241978. (in Japanese)

Chang, T., Takahashi, D.: Willingness to pay and willingness to accept for farmland leasing and custom farming in Taiwan. In: The 30th Triennial Conference of the International Association of Agricultural Economists. (2018). doi:https://doi.org/10.22004/ag.econ.277426

Chen, H.H.: A study of Taiwan's economic development and integrated rural construction (in Chinese: Wo Guojing Ji fa Jhanyunong Cunzong Hesingjian Shejhihyan Jiou), agricultural. Finance 17, 1-31 (1987) 
Ferng, J.: Effects of food consumption patterns on paddy field use in Taiwan. Land Use Policy 26(3), 772-781 (2009). https://doi.org/10.1016/j.landusepol.2008.10.005

Hoshi, J.: The future of the leaders of community development [in Japanese]. In: Wakabayashi, M., Lenaga, M. (eds.) Invitation to Taiwan studies, pp. 255-264. University of Tokyo Press, Tokyo (2020)

Hsu, C.-M.: The uniqueness of the ritual circle for the Han Chinese community in Taiwan. Chin. Cult. Renaiss. Mon. 11(6), 59-68 (1978). (in Chinese)

Ishida, H.: A study on development process of Han villages in Taiwan and their social structures: a case study of Hong lineage in Jialao Village, Caatun Township, Nantou Prefecture. Econ. Rev. Kansai Univ. 31(3), 545-597 (1981). (in Japanese)

Ishida, H.: Regional and kin structure of Han's villages in north-west Taiwan: a case study of rural communities in Xin-wa and Guan-yin township, Tao-yuan Prefecture. Econ. Rev. Kansai Univ. 33(5-6), 441-493 (1984a). (in Japanese)

Ishida, H.: A study on formation and development of Han's villages in north-east Taiwan: a case study of villages in Lan-yang Plains, I-Lan Prefecture. The Econ. Rev. Kansai Univ. 34(3), 347-392 (1984b). (in Japanese)

Katchova, A.L., Ahearn, M.C.: Farmland ownership and leasing: implications for young and beginning farmers, RePEc - Research Papers in Economics (No. 1639-2016-135163) (2014)

LeSage, J., Pace, R.K.: Introduction to Spatial Econometrics, 1st edn. Chapman \& Hall/CRC, New York (2009)

Lin, K.C: Policy options for agricultural land use in Taiwan. In: Koppel, B., Young Kim, D. (eds.) Land Policy Problems in East Asia: Toward New Choices, A Comparative Study of Japan, Korea and Taiwan, pp. 433-456. East West Center and Korea Research Institute for Human Settlements, Honolulu, Hawaii (1993)

Okada, Y.: Ceremonial areas in the North Formosan villages. Jpn. J. Ethnol. 4(1), 1-22 (1937) (in Japanese)

Raup, P.M.: Disaggregating farmland markets. In: Moss, C.B., Schmitz, A. (eds.) Government policy and farmland markets: the maintenance of farmer wealth, 5, pp. 15-26. Macmillan, New York (2003)

Robison, L.J., Myers, R.J., Siles, M.E.: Social capital, the terms of trade, and the distribution of income (No. 1099-2016-89430) (1999) doi:https://doi.org/10.22004/ag.econ.11546

Robison, L.J., Myers, R.J., Siles, M.E.: Social capital and the terms of trade for farmland. Rev Agric. Econ. 24(1), 44-58 (2002a)

Robison, L.J., Schmid, A.A., Siles, M.E.: Is social capital really capital? Rev. Soc. Econ. 60(1), 1-21 (2002b). https://doi.org/10.1080/00346760110127074

Shieh, G.-S.: A sociography of Ping-Lin, Taiwan: Wage, Governmentality and Total Social Categories. Institute of Sociology, Academia Sinica, Taipei (2010) (in Chinese)

Siles, M., Robison, L., Johnson, B., Lynne, G., Beveridge, M.D.: Farmland exchanges: selection of trading partners, terms of trade, and social capital. J. ASFMRA 63(1), 127-140 (2000)

Takahashi, D., Chang, T., Shobayashi, M.: The role of formal and informal institutions in farmland consolidation: the case of Shiga Prefecture. Japan. Int. J. Commons 12(2), 80-107 (2018). https://doi. org/10.18352/ijc.829

Tan, S., Liu, B., Hannaway, D.: Age, social capital, and herders grassland renting decisions in Inner Mongolia, PR China. No. 277034. International Association of Agricultural Economists, Conference in Vancouver, British Columbia (2018). https://doi.org/10.22004/ag.econ.277034

Taylor, M.R., Featherstone, A.M.: The value of social capital in cropland leasing relationships. No. 235975. Agricultural and Applied Economics Association (2016). doi:https://doi.org/10.22004/ag. econ. 235975

Taylor, M.R., Featherstone, A.M.: The value of social capital in farmland leasing relationships. Agric. Fin. Rev. 78(4), 489-496 (2018). https://doi.org/10.1108/AFR-08-2017-0067

Teshome, A., de Graaff, J., Kessler, A.: Investments in land management in the north-western highlands of Ethiopia: the role of social capital. Land Use Policy 57, 215-228 (2016). https://doi.org/10. 1016/j.landusepol.2016.05.019

Publisher's Note Springer Nature remains neutral with regard to jurisdictional claims in published maps and institutional affiliations. 